\title{
Impact Of Micro-Credit On Women Empowerment: A Case Study Of Rural Pakistan
}

\author{
Ambreen Fatima \\ Syed Faizan Iftikhar \\ \& \\ Khurram Iftikhar \\ Applied Economics Research Centre \\ University of Karachi
}

\begin{abstract}
It is widely argued that discrimination on the basis of gender leads to social exclusion and locks people into long-term poverty traps. Thus the need for poverty alleviation schemes that target women and children have long been a priority for development of communities around the world, and also including Pakistan. It is also a widely recognized fact that poverty can be overcome if women are provided access to economic and educational opportunities, as well as autonomy to take advantage of such opportunities. The provision of credit, especially micro-credit, has now become an effective tool and successful strategy for poverty reduction among women. The main objective of this study is to determine the impact of micro-credit on women empowerment, specifically on women mobility. The study analyzes the impact of credit on women's role in decision-making, besides estimating the changes in their confidence level. It also evaluates the advantages of women keeping assets in their name. Consequently, the study concludes that the impact of micro-credit has played a positive role on women empowerment, specifically in raising awareness in enhancing their capacity to build assets, move around freely and contributes to various household level economic decisions.
\end{abstract}

Keywords: Micro-finance Institutions, Gender, Empowerment, Socio-Economic Constraints, Poverty, Rural Areas of Pakistan.

\section{تلخيص}

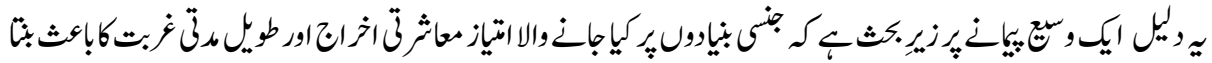

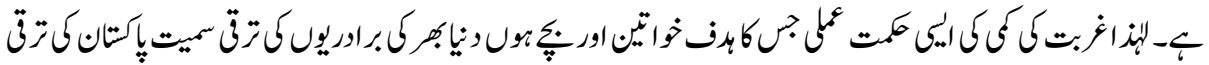

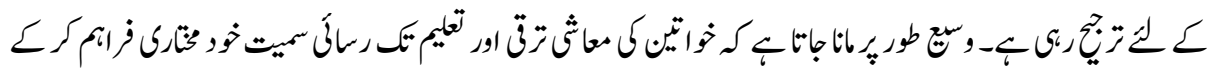

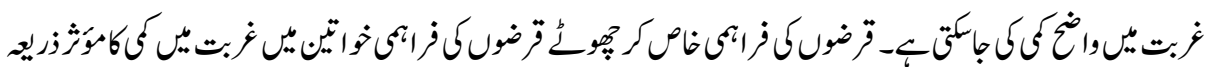

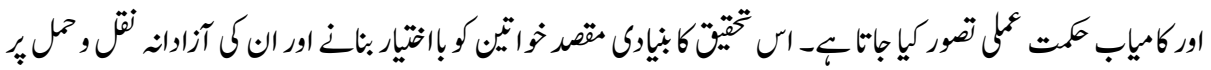

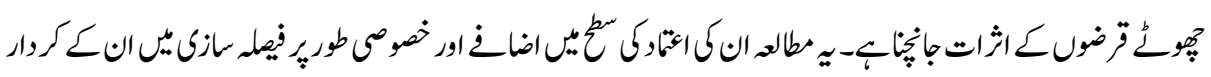

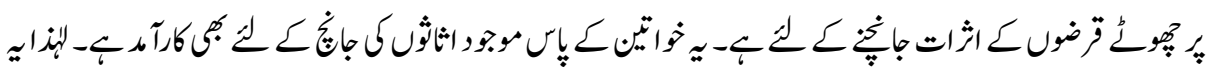




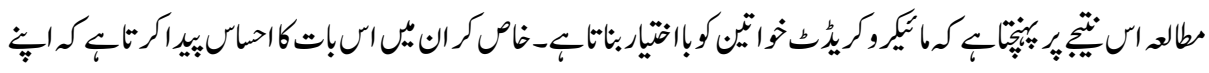

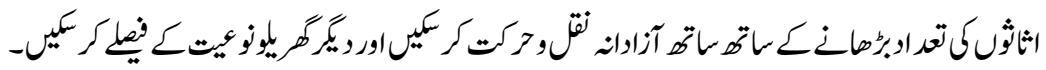

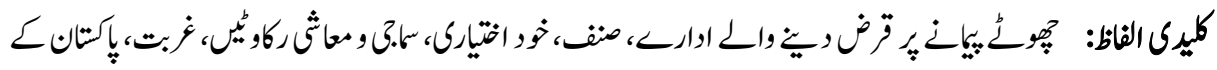

$$
\begin{aligned}
& \text {, }
\end{aligned}
$$

\section{Introduction}

This paper is an attempt to explore issues pertaining to credit services among rural females of Pakistan. Microcredit programs for women are seen increasingly as an effective poverty alleviation intervention by development agencies, and widely assumed that there is a clear and direct relationship between access to credit and an increase in the status of women within their households and communities. The provision of credit is believed to lead to empowerment of women (Kabeer 1998; and Mayoux 1998). The basic theory behind this concept states that microcredit programs empower women by giving capital in their hands which allows them to earn independently. This economic empowerment is expected to generate self-esteem, respect and other forms of empowerment among beneficiaries. Although the ability of a woman to transform her life through access to credit services also depends on other factors as well, some of them are linked to her personal abilities while others are dependent on her surroundings and environment, like socio-economic and cultural background. The social and cultural norms decide the status of women in a society.

Several studies have documented the improvement in women's status within the household resulting from access to credit, mainly focusing on female employment, concluding that the magnitude of female labor force participation is larger in enterprises financed through credit. For example, Rahman (1986), Rahman and Khandker (1995) and Pitt and Khandker (1998) observed that female labour force participation rate shows a positive response towards micro-credit program. Self-employment of women and total household employment is higher in areas with credit programs. However, how much this employment generation can be considered as a step towards empowerment, will depend on the interlinked changes that result due to changes in employment opportunities. Gibbons and Todd (1993) observe that credit help those poor women with less assets to increase their earning and as a result their social position within the family and community improves remarkably.

Also, Zohir (1990) observed a positive influence on the status of woman in society and her social influence pertaining to security. Zohir also concludes that former (status of 
women) arises due to credit disbursement to female members who now have greater influence on family matters. Zohir (1990) obtained positive impact of empowerment on social aspects, while Kabeer (1995) observed that success of microcredit program, especially empowering women, are understood in a more wider perspective. A comparison of women's self-employment with women's wage employment in large scale industries in the urban areas shows that women's wage employment is observed to bring about even a greater social change, as it promises a regular source of income. This change in wage employment brings more rapid changes than earnings in rural areas (Rahman 1994).

Moreover, most of these case studies on the impact of micro-credit for women empowerment have been undertaken for South Asia (mainly in Bangladesh), given the longer presence of micro-finance institutions here. The picture presents positive evidence as well as limitations of the program to bring changes in women status (Dubel, 2002). This may be because of the complex relation between social and gender norms in South Asian countries. The non-availability of sufficient quantitative data also limits the demonstration of the impact. Assessment of poverty, empowerment and inequity requires quantitative information as well as qualitative information. Given the dynamic and complex processes involved in social changes, monitoring over a long term is also required.

Mayoux, (1997) pointed out that provision of credit leads to the setting up or expansion of micro-enterprises which provide a range of potential impact on women. Some of these are: increasing women's income level; and control over income. This leads to greater level of economic independence, access to networks and markets, wider information and vast experience of the outside world than within the home, possibilities for development of other social and political roles, enhancing perceptions of women's contribution to household income and family welfare, increasing women's participation in household decisions regarding expenditure on women's welfare, more general improvement in attitudes towards women's role within the household and in the community.

Finally, the role of gender in development is hard to understand without understanding the socio-economic and cultural background. The concept of empowerment is meaningful only within specific context. However, the degree of consensus on the conceptualization of empowerment is not readily apparent in any literature, because of the variation in terminology used therein. The literature contains a range of terms, concepts, and data that are relevant to assess "empowerment". Various efforts have been made in recent years to develop comprehensive frameworks delineating the various 
dimensions along which women could be empowered [see for example; CIDA (1996), Jejeebhoy (1995), Kishor (2000), Hashemi et al. (1996), Schuler et. al (1997), Stromquist (1995), Sen (1999)].

Considering such diversified dimensions of empowerment mentioned in these studies, the main objective of our study is to measure the extent of empowerment, given those various dimensions reflected in the literature. The study will also analyze the impact of credit and factors related to women's own capabilities and socio-economic status of the households on empowerment, as well. The study first develops an analytical model to measure empowerment and after developing appropriate indices to measure empowerment, logistic model is analyzed to determine the impact of credit on empowerment.

The introduction (Section 1) of our study is followed by the analytical model which measures empowerment in Section 2. Section 3 discusses the factors influencing empowerment other than the credit and data employed for the assessment. Section 4 evolves the results of our findings, whereas the conclusion and some policy recommendations are presented in Section 5.

\section{Analytical Models to Measure Women Empowerment}

An important part of the process in generating an analytical model to measure women empowerment is to identify culturally appropriate indicators for $i^{1}{ }^{1}$. The choice demonstrates an important but complex process of combining quantitative and qualitative knowledge of a setting. It has always remained a matter of concern for measurement to identify appropriate measures of empowerment and other associated behavioral indicators. To accomplish this task, AERC (1998) data is used in combination with a theoretical model developed by an earlier qualitative research undertaken by Hashemi and Schuler (1993); to be called HM hereafter.

The qualitative research undertaken by HM identifies the dimensions of empowerment through in-depth interviews of credit participants for Bangladesh. The work of HM (1993) provided a starting place for the development of a theoretical model in measuring women empowerment, and identified six dimensions of empowerment based on activities pointed out by women as important aspects for their day-to-day functioning. Moreover, HM (1993) also discussed that these dimensions to be interrelated, pointing out that any change in one dimension would likely affect other dimensions, as well.

HM (1993) also argued that some dimensions of empowerment are conducive to quantitative measurement while others are not. Therefore, dimensions of empowerment should be modified for quantitative analysis based on the availability of appropriate measures. Although some dimensions are identified as theoretically important, but their 
measurements prove to be problematic, specifically from the data of AERC (1998). Hence, out of these six dimensions of empowerment used by HM (1993), only four are being used by us in our present study. The detailed discussion on these four dimensions is given in the following section.

The first dimension used is "mobility", which is limited to measure the extent of women's mobility within or outside the village. HM (1993) argued that information related to women's mobility can be elicited by asking questions about where they go, how often, and with whom they moved around. The AERC (1998) data includes a battery of questions regarding women going alone or with someone to various places such as hospital, bank, market, field and other's houses. Within these questions it was desirable to measure general mobility and not place-specific mobility. Hence, these questions were again repeated by asking individuals whether they visited these places, outside the village. The coding of these indicators presumes that women going outside the village alone are the most empowered.

The second dimension used in our study is "economic security". It includes ownership of property and/or other economic assets. The ownership of both productive and nonproductive assets, as well as ownership of house, are considered for measuring this dimension, which HM assumes to be necessary for the provision of economic security to women.

The third dimension of women empowerment pertains to the "status and decisionmaking power within the household". It includes decisions on allocation of resources within the household, control over money and purchases, and enhanced status in the family. According to Alam (2000), even small purchases for the household are usually done by men in rural areas. However, HM (1993) reported that the ability to make small purchases is common for women and thus not a meaningful measure of empowerment. Therefore, a distinction exists between the abilities of women to decide in making small and large purchases. To account for the possibility that making small and large purchases reflect different aspects of women's power, two separate dimensions were again taken into consideration; viz. (i) the ability to make small purchases and (ii) the ability to make large purchases.

The fourth and final dimension used in our study is linked with the "participation of women in non-family groups." This dimension includes participation in NGO programs, and in a forum for creating a sense of solidarity with other women, besides taking group actions. In rural areas women typically lack an identity outside their home, which reduces their emotional dependence on their families and, by building alternative support networks, increase their potential to assert themselves within the family, and as well as, in the community. The AERC (1998) asked questions about women's group membership 
and involvement in-group actions, but variations in these questions are too small to be useful. Very few women in the survey reported their participation in group actions. Since HM (1993) argued that this dimension is significant because it indicates women's level of interaction with non-family members, another related variable is chosen. The AERC (1998) asked women whether they visited other homes, markets, banks, fields, and/or hospitals in other villages alone, and going out of the village is often assumed as visiting non-family members. Therefore, this is also considered as an appropriate measure of interaction with non-family members. In the model, this dimension is specified towards those women who go to other villages, and those women who visit to places outside the village alone, are considered as the most empowered.

The original theoretical model of women empowerment proposed by HM (1993) is thus transformed into the theoretical model with four dimensions of empowerment and reported as indicators of empowerment. The differences in the models stem from data constraints. The indicators are constructed as scale variables. The components are given proper weights. All of the operational measures of empowerment employed in this analysis reduce the empowerment data into dichotomous variables. The cutoff points for empowered versus underpowered is based on percentage distribution of each dimension. Each dimension attempts to separate those women who stand out as being relatively more empowered than others. The cut-off points for women empowerment indicators are made at around $25^{\text {th }}$ to $50^{\text {th }}$ percentile. Since in most cases, a one space downward move on the scale classifies more than half the respondents as empowered. Whereas one space upward move excludes most of the respondents. Hence, the decisions on the cut-off points are easily noted down.

The variables used to develop empowerment indicators are discussed below.

\section{Operational Measurement of Empowerment Indicators:}

Details of the four indicators: (i) decision making; (ii) mobility; (iii) ownership of assets; and (iv) self-confidence, which cover a wide range of attributes are comprehensively measured are mentioned below.

i) Decision Making Index (DMI)

DMI refers to the extent of women's ability to make decisions regarding financial matters (making small and large purchases, as well), including purchases made for personal use (i.e. cosmetics and jewelry), in coordination with other family members. The small purchases include household items of daily use while large purchases refers to purchase of land and houses, etc. One point each is given for purchasing small items whereas two points each for purchasing large items. As far as decision regarding the purchase of jewelry and cosmetics is concerned, one point each is given again to the respondent having the power to make purchases 
on her own. A respondent with a score of one or better is classified as empowered and coded as one ${ }^{2}$.

\section{ii) Mobility Index (MI)}

MI refers to the physical mobility of women either alone or with others, within or outside the village. Considering degrees of mobility [allowed to move alone or with others] and issue concerning whether the mobility is restricted within or outside the village, different weights are assigned. First of all, one point each is given if the respondent is allowed to visit any of the following places within the village:
i. Markets
ii. Fields
iii. Hospitals
iv. Others' houses

Then two points are assigned if the respondent is allowed to go to the banks within the village. Furthermore, a four point rating scale is used to measure the degrees of mobility. Four points are assigned for visiting each of these places alone, three points for visiting with children, two points for visiting with females and one point for visiting with male only. Additional two points is given if the respondent has visited these places outside village/near village. A respondent with a score of twenty or better is classified as empowered and coded as one.

\section{iii) Ownership of assets/Economic Security Index: (ECSCI)}

Three types of assets, comprising of different items are selected for the development of index regarding ownership of assets. These assets provide economic security to females and include:

i. $\quad$ Productive assets - Livestock, Cash Saving and Land

ii. Unproductive assets - Jewelry and household daily use items (radio, TV, etc)

iii. Ownership of house. This item consider separately (not included in the unproductive assets) because ownership of house means women is far more empowered than those women who only own jewelry or household daily use items.

One point each is given if the respondent owns jewelry and items of daily use by the household. Two points are assigned if the respondent owns a house whereas three points are given if she owns any of the productive assets (livestock and land). Again, two extra points are given to the respondent who claims that they themselves own these assets and one point is further assigned to those who respond that they have some kind of joint ownership of these assets. However, females who stated that their family or spouse own these assets are considered to be economically underpowered and assigned the score of zero. A respondent with a score of three or better is classified as empowered and coded as one. 


\section{iv) Self-Confidence Index (SCI)}

SCI refers to the extent of women's ability to participate in non-family groups. This dimension includes participation in CBO's, NGO and Bissi Committee programmes that involve group actions. Participation in such programmes creates sense of solidarity with other women. One point each is given to individual who participated in these groups. As discussed earlier it also includes visits to places alone within or outside the village as another indicator of women's selfconfidence. Hence, one more point is given, if they visited the places alone. The respondent is classified as empowered if she has a score of one or more.

\section{v) Cumulative Empowerment Index (CEI)}

A composite/cumulative index is calculated by summing up all the indicators. A woman is classified as empowered if she attains a score of two or more.

\section{Determinants of Empowerment}

Indices developed to compute cumulative empowerment index (CEI) are then used to carry out multivariate analysis by using logistic models, in order to measure the degree to which borrowing and other specific autonomous factors affect these indices and CEI. The Model includes other autonomous factors as determinants of women empowerment as well. Mizan (1994), while working on Grameen Bank's participation concluded that credit places a significant impact on women's decision-making power after controlling for demographic factors and other household characteristics. The inclusion of some of these factors introduces the problem of endogeneity. For example, Basu (2006) argued that empowerment itself is endogenous. According to Basu (2006) the literature modeling the impact of intra-household balance of power on decision-making tends to ignore the opposite relation i.e., the effect of household decisions on balance of power. According to Roushdy and Namoro (2007), male and female decision-making power relatively depends on their individual and some common household or social characteristics, determined within the model.

Hou (2011) working on Pakistan Standard of Living Measurement Survey data, on the other hand, rejected the endogeneity assumption if the index is based on the women's control over resources, contribution in decision-making process, social networking and basic human nature or conducts. Hou (2011) argued that bargaining power is often measured in the literature by the relative income of the male and female or by the ratio of number of years of schooling by female to male, on the assumption that women bringing more income or having a higher level of education have greater bargaining power. These two indicators are often endogenous because income and education are major determinants of budgetary share, as well. Following Hou (2011) view point, this study also considers the index constructed as exogenous. 
Although a number of attempts were made in the formulation of the model based on the level of statistical significance, five models appeared to be more appropriate and within our scope. These models primarily involved fixed set of independent factors (along with borrowing either to generate economic activity or for consumption) regressed against the four indicators and a cumulative index of empowerment. Since all the indicators of empowerment computed reduce the empowerment indices into dichotomous variables as explained earlier, Logit Model is used to express any relationship between borrowing and indicators of empowerment The specific model tested is based on the following function:

$$
E I_{l}=\beta_{0}+\beta_{1} \sum_{i=1}^{2} C R D T+\beta_{1} \sum_{j=1}^{n} H H S P+\beta_{1} \sum_{k=1}^{m} F M S P+\mu
$$

Where;

\begin{tabular}{|c|c|c|}
\hline$E I$ & $=$ & $\begin{array}{l}\text { Empowerment Indices (mobility, decision-making, economic } \\
\text { security, self confidence and cumulative index). }\end{array}$ \\
\hline$C R D T$ & $=$ & $\begin{array}{l}\text { Credit specific variables (credit for consumption and productive } \\
\text { purpose) }\end{array}$ \\
\hline HHSP & $=$ & Vector of Household level variables \\
\hline$F M S P$ & $=$ & Vector of female specific variables \\
\hline$l$ & $=$ & number of Indices, here 5 in number \\
\hline$i$ & $=$ & type of credit, here 2 in number \\
\hline$j$ & $=$ & Indicators of household characteristics, here 13 in number \\
\hline$k$ & $=$ & Indicators of Female characteristics, here 6 in number \\
\hline
\end{tabular}

Separate regressions are estimated for the four indices included in EI. HHSP stand for the vector of household specific variables. Variables included herein are household socio-economic, cultural and occupational status, such as ownership of land, household income and its regional background. The literature also pointed out that female's own characteristics (FSP), such as woman's marital status, age and her contributions to household income, indicate important factors determining her empowerment (Goetz et al 1996, Hashemi et al 1996). As such these variables are included in the model as well. The detailed description of the variables included in the model is given in Table 3.

\section{Data Employed}

In order to analyze the empowerment reliance on quantitative structured surveys, rather than on qualitative participatory research methodologies, many limitations emerge consequently. Firstly, quantitative surveys are limited in number and secondly, quantitative surveys have often been conducted by micro-finance organizations to evaluate their programmes. Hence only their target areas or clients are covered in these surveys, particularly in case of Pakistan, these kinds of surveys are hard to locate and 
deemed to be less useful. The only reliable and viable study taken into account from both qualitative as well as quantitative aspects of the programme, was undertaken in 1998. The study was commissioned by the State Bank of Pakistan and conducted on rural financial markets in Pakistan, as part of a series of studies by the AERC. To date, this is the largest study on the subject covering more than 6,000 households and 24,000 respondents and hence, assists us in empirical assessment. It uses the data collected by AERC (1998). Furthermore, considering the objective of this study data of individual female above 14 years of age is selected. Thus, the final data used for this study consists of 8,663 females covering 4,392 households.

\section{Empirical Analysis}

In the rural areas of Pakistan, traditions and restrictions imposed by the family often influence ability of women to take control of their own lives. However, from Table 4, it is evident that most of the females with provisions of credit are more empowered than females otherwise. According to the cumulative index of empowerment out of 1005 borrowers, $84 \%$ are empowered, whereas from among the non-borrowers, $74 \%$ females are empowered. It is also evident from the Table that except for self confidence and decision-making indices, other two indices and the cumulative index depict a significant impact of borrowing on empowerment. For example, index related to economic security shows that $71 \%$ of borrowers are empowered while for non-borrowers this percentage is only $53 \%$, which further confirms the positive impact of credit on empowerment.

Although it is evident from Table 4 that credit did empowers women but this impact may vary with their age, education and socio-economic position within their household. Since it cannot be assumed that all women can participate and benefit from the micro-credit programmes, with the same degree or level, it was considered meaningful and viable to control the above stated factors in the model. This will assist us to gain full knowledge of the impact of credit on women empowerment. To analyze any possible association between empowerment and factors determining empowerment (including credit) simple averages are estimated.

\section{Association between Factor Affecting Empowerment and Empowerment Indices}

Table 5 presents the average values of empowerment indices by gender, amount of credit, female and household characteristics. It is evident from the Table that average values of empowerment indices increase with the raise in the amount of credit. Except for the amount of credit higher than 25000, average values of empowerment indices show increasing trend, which enhances the decision-making aspect of females. However, no affect on other indices is evident from the Table. The average values fluctuating from the 
lowest amount of credit to the higher value of male credit are, of course, evinced in the Table.

Females between the age group of 31 to 60 years also appeared to have higher average values of empowerment indices, which traced out non-linear assumptions between age of females and empowerment (average values of empowerment indices increased with the increase in age up to 60 years and then declined). The education among females education was also seen to be positively associated with the average values of empowerment indices as reflected among females having education level higher than Intermediate.

Comparing average values across different marital statuses (married/widowed/divorced/ separated) shows that except for decision making average values of empowerment indices are higher for them. Average values across age group of household head exhibited no particular pattern. However, average value of cumulative empowerment index was higher among the household head belonging in age group between 31-50 years. It was also very interesting to note that females belonging to same age groups also claim higher average values. No particular pattern is once again apparent for the education levels and employment status of household's head.

Furthermore, farm size (a symbol of social norms and prestige) presents an interesting scenario. Females belonging to families having large land holding had greater say in decision making and were economically secure (as evident from the higher average values of indices) while on the other hand women belonging to families having land holding just subsistence to support the family needs have higher values of mobility and self-confidence indices. In cumulative empowerment index, females with subsistence land holding have higher average values of empowerment index. Finally, on exploring the effect of region (keeping aside the females residing in AJK), the study finds that the females belonging to rural Punjab have higher values of mobility and confidence indices while females from Sindh have greater say in decision-making and sustain greater economic security.

\section{Logit Analysis}

Keeping in view the association presented in above section, logit estimate of factors determining empowerment is analyzed. The empirical findings are presented in Table 6 and discussed below:

\section{a) Credit}

Results presented in Table 6 provide strong evidence of the positive effect of credit taken for productive/development purposes on women empowerment. The 
results are consistent with the hypothesis that women participation in micro-credit programmes help in employment generation which bring autonomy, leading further to their empowerment. The phenomenon works in the following manner: credit enhances women participation in economic activities outside home that increased their financial contribution within the house. Their enhanced support to the family's financial need brings self-respect to them and the family. This ultimately increases their role in decision-making, provides them greater access to financial and economic resources, and enhances their mobility, subsequently leading to recognition of self-worth and autonomy. Therefore, in the context of credit it can be concluded that it has increased autonomy of females not only within the household but also in the community and has increased their ability to take control of their own life. This might ultimately affect poverty and vulnerability among females in the long run. All component indicators show the same positive relationship. However, the affect of credit is not significant on decision-making power and on self-confidence.

As far as loan for consumption purposes is concerned, it affects the overall empowerment index significantly but on component indicator its affect is positive and significant only for mobility and in providing economic security. The possible reason behind the negative effect of consumption loan on female decision-making power and self-confidence increases in debt burden. The consumption loan often results in increase in debt burden on females that ultimately reduces their ability to work efficiently, which further increases their dependency and confidence. The literature also stresses that women who control their loans and invest efficiently for productive purposes have greater chance of being empowered, whereas women who hand over the loans to their husbands are less likely to be empowered. The same effect was expected for the consumption loan as it does not translate into capital formation. Although male credit has significantly enhanced the overall empowerment but negative effects on three of the indicators of empowerment are apparent widely. It negatively affects their say in the decision-making process, and their abilities in acquiring assets in their name, besides their interaction outside family.

As discussed earlier, the ability of a woman to transform her life through access to financial services depending on other factors as well, not only on the availability of credit. Some of these aspects are linked to her abilities and household characteristics while others are dependent upon social and cultural environment they live in.

The following discussion explores and provides detailed clarifications on some of these factors. 


\section{b) Employment Status}

Females being employed had enhanced overall empowerment of women further confirming the hypothesis that employment had generated income leading to financial assistant to families which brought self worth for the females in the eyes of household members; hence had positive impact on empowerment. As far as household head occupation status (either self employed or employee) is concerned it was found out to be discouraging females overall empowerment. In the component indicators the affect was significant only for the mobility index.

\section{c) Marital Status}

Marital status also affects female empowerment. In the overall empowerment scenario unmarried female have lower probability of being empowered while married females do enjoy some forms of empowerment, but the affect was not significant on the overall empowerment.

d) Age Female's age have non-linear relationship with empowerment indices (as evident from the sign of the coefficient of age and age square). An increase in age first increases the probability of females being empowered reaches its maximum point and then decline (as evident from Table 5 that after 60 years of age, average values of empowerment indices decline). Women age between 30 to 60 years enjoy greater autonomy. For the overall empowerment index and mobility index positive coefficient of household head age and negative values of its square again shows the non-linear relationship between household head age and empowerment of females. The reason could be the cultural values that prevail in rural areas and often limit females to take control of their life in the presence of elders. Considering the component indicators separately, inverse relation appeared for the indices of decision-making power, assets keeping and for self-confidence index. The possible explanation could be that in presence of elders, free mobility of females is restricted but after a certain age women do gain some power to exercise it on other dimensions of life (power to decide and keep assets).

\section{e) Education}

The effect of female education on their empowerment indicates that education had improved their well being by providing them more economic security and improving their decision making power. However, its affect is insignificant on overall empowerment of females. As far as years of education of household head is concerned, this variable is found to have significant negative impact on overall empowerment of females. Considering the impact separately on individual indicators, result show that total years of schooling is positively and significantly influencing power to take decisions and keep assets by their name while for mobility and self confidence its influence was negative. The study concludes that 
education brings some respect and self worth for females to take decisions and keep assets but enhancing female mobility and self-confidence required changes in the patriarchal values embedded in the local traditions and culture that predetermined the social value for gender which restricted female's mobility and their free interaction in groups.

f) Regional/Cultural Variation

The provincial dummies, representing cultural and regional values, also show significant barriers in the provision of empowerment to females. In such patriarchal society, women are often confined within the house rendering household work and taking care of children. They are restricted to undertake any economic activity and thus always live under the shadow of male who consider as the dominant member in the household and in community. In such situations, it was noteworthy that culture does not restrict females to keep assets by their names, because buildings or keeping assets by household by both members, was seen as enhancing social and economic status.

g) Social Norms

The affect of variables explaining social status of the household was overall insignificant. In the cumulative empowerment index the affect was negative for females belonging to household having large land holding while, for other categories its impact was positive. For individual indicators, females belonging to families having large land size were allowed to take decisions, keep assets in their names and allowed to interact freely with others in the village and outside, even alone (enhancing self confidence among them). Females belonging to families having medium or small land holding were empowered in all the dimension of empowerment. Hence, our study concludes that these norms influence different dimensions of empowerment differently; i.e. If females belonging to families having different sizes of land holding are restricted in this dimension, they find a way to gain empowerment in other dimensions.

\section{h) Household Demographic Situation}

Although dependency ratio is found to be empowering females to take decisions and keep assets but self-confidence retards their capabilities to take control of their lives. An increase in this variable implies greater workload, reducing their ability to take employment opportunities outside home which in-turn impacts their autonomy. As evident from the literature that micro-Finance programmes have raised legitimate concerns about the potential negative impact that programme can have on women. Among such impact was the increase in workload. Due to involvement in income generating activities and the responsibilities within the household micro credit programmes often resulted in overwork for females which ultimately impacted their economic activities outside home, such as their 
interaction in non family groups thus reduced their self-esteem and affected their confidence level.

Moreover the proportion of adult women in the households, included in the model to assess the effect of household composition on the respondents 'empowerment' indicated that it had enhanced overall empowerment of females through promoting their free mobility and their ability to interact freely with others outside home but it was reducing the women ability to keep assets by their names and their say in decision making. Since the increase in the proportion of females or individuals (household size) in the house accumulation of assets and transformation of power to individual decline, may hamper their empowerment.

\section{i) Household Economic Status}

Although household per capita annual income promotes females to keep assets in their name, take decision and move freely, its influence on overall empowerment positively and significantly apparent, but will not enhance their self-confidence. Surprisingly, it is found to be reducing their ability to poise. The self-confidence index is based on female ability to interact freely with others and it is determined by the household's economic status. It is rather dependent on women's own potential that could be influenced by giving credit to generate employment (also evident from the positive significant coefficient of credit for productive purposes).

\section{Conclusions and Discussions}

Feminization of poverty is an economic problem and its importance in raising women's economic productivity has been increasingly recognized as a crucial element in the design and implementation of development projects to create alternative strategies for reducing it. To achieve the goal, "Power" is assumed to be an essential element for women empowerment. However, power is referred to be the sense of internal strength, right to determine one's choice of living, and the right to influence the direction of social change. In recent years, micro-financing and micro-credit for women's small and microscale enterprises are viewed and discussed to be the most effective ways to promote and support women's self-employment determinants that ultimately provides an effective and significant impact on women empowerment. This article evaluates the role of microcredit in empowering women.

The analysis used survey data of rural financial market conducted by AERC in 1998 to measure the affect of credit on the four dimensions of empowerment besides working on a composite indicator of empowerment. It also addressed the issues related to female own characteristics, household characteristics and regional values which influence their empowerment. The study concludes that credit empowers women by strengthening their economic roles and eventually increasing their ability to contribute in support of their 
family. It is also argued that there are certain other mechanisms that also assist to influence empowerment of women, like older age, female being employed, proportion of adult females in the house, male credit, per-capita annual income, along with age, education, occupational status of household head, and regional dummies.

One most important factor that hinders the enhancing empowerment is found to be 'education', although its role is assumed to have greater and effective significance in empowering women. Information dissemination, raising awareness, capacity building, and translation of skills into practice (all being the resulting outcome of education) are assumed to increase women's economic options and promote their sense of worth in the family, locality and elsewhere. Basic literacy often helps women to acquire knowledge and skills for improving and developing their tasks in all the fields. Poor rural women lack such types of educational resources, which help in improving skills and enhancement of knowledge to use capital (credit) efficiently.

In addition to other factors mentioned above, credit is found to be an influential element to enhance female's abilities to control assets and as well as in helping them to establish an identity outside the family. Such activities provide them due experience and wider self-confidence to move freely around, and take decisions regarding large and small purchases, along with purchases related to their personal and individual own self. On the whole, this study confirms the hypothesis that credit impact women empowerment positively.

\section{End Notes}

1. A theoretical framework based on in-depth knowledge of the culture and norms that define behavioral expectations for women must be developed before analysis can be performed.

2. In all the empowerment variables "not empowered" is coded as zero.

\section{References}

AERC (Applied Economics Research Centre) (1998). Rural Financial Market Study (Phase II), University of Karachi, Karachi, Pakistan.

Alam, Nurul (2000). Women, Households, and Communities and Care of Sick Children in Rural Bangladesh, Faculty of Medicine, University of London, London. 
Basu, K. (2006). Gender and Say: A Model of Household Behaviour with Endogenously Determined Balance of Power, Economic Journal, vol.116, pp.558-580.

Canadian International Development Agency (CIDA) (1996). Guide to Gender-Sensitive Indicators, Ottawa: CIDA.

Dubel, Ireen, (2002). Challenges of Gender Mainstreaming: The Experiences of Hivos Presentation at Women's Worlds 2002, Kampala, 21-26 July 2002.

Gibson, A. (1993). A Review of NGO Credit Projects Funded Under the Joint Funding Scheme, Rural Development in Practice,vol.3, pp.184-195.

Goetz. M. \& R.S. Gupta (1996). Who Takes Credit? Gender, Power and Control Over Loan Use in Rural Credit Programs in Bangladesh, World Development, vol.24:1, pp.45-63.

Hashemi, Syed M., Sidney Ruth Schuler, \& Ann P. Riley (1996). Rural Credit Programs and Women's Empowerment in Bangladesh, World Development, vol.24:4, pp.635-653

Hashemi, Syed Mesbahuddin \& Sidney Ruth Schuler (1993). Defining and Studying Empowerment of Women: A Research Note from Bangladesh, in JSI Working Paper No.3. Arlington, Virginia.

Hou Xi. (2011). Women's Decision Making Power and Human Development: Evidence from Pakistan. Policy Research Working Paper No. 5830, The World Bank.

Jejeebhoy, Shireen J. (1995). Women's Education, Autonomy and Reproductive Behaviour: Experience from Four Developing Countries, International Studies in Demography, IUSSP, Oxford: Clarendon Press.

Kabeer, Naila (1995). Envisioning Gender and Development Issues in the Coming Decade: Paper prepared for SIDA Workshop on Gender and Development Cooperation in "A Vision for Gender and Development", Ministry of Foreign Affairs, London.

Kabeer, Naila (1998). Money Can't Buy Me Love? Re-Evaluating Gender, Credit and Empowerment in Rural Bangladesh, IDS Discussion Paper No.363, Institute of Development Studies, University of Sussex. 
Kishor, Sunita (2000). Women's Contraceptive Use in Egypt: What Do Direct Measures of Empowerment Tell Us? Paper prepared for presentation at the Annual Meeting of the Population Association of America, March 23-25, 2000, Los Angeles, Calif.

Mayoux, L. (1997). The Magic Ingredient? Microfinance and Women's Empowerment, Paper presented at the Conference. http://www.gdrc.org/icm/wind/magic.html (A Briefing Paper prepared for the Micro Credit Summit, Washington.

Mayoux, L. (1998). Participatory Learning for Women's Empowerment in Micro Finance Programs: Negotiating Complexity, Conflict and Change. IDS Bulletin 29: 39-40.

Mizan (1994). Mizan, Ainon Nahar. In Quest of Empowerment: The Grameen Bank Impact in Women's Power and Status. Bangladesh, Dhaka: The University Press Limited.

Pitt, Mark M. \& Shahidur R. Khandker (1998). The Impact of Group-Based Credit Programs on Poor Households in Bangladesh: Does the Gender of Participants Matter? Journal of Political Economy 106 (October): 958-96.

Rahman, A. (1986). Informal Credit Markets in Rural Bangladesh - Study Outline, Dakka: Unpublished Draft Proposal submitted to Asian Development Bank, Bangladesh Institute of Development Studies, 34.

Rahman, H. Z. (1994). Rural Poverty Update, 1992-93, Dhaka: Bangladesh Institute of Development Studies.

Rahman, Rushidan Islam \& Shahidur R. Khandker (1995). Role of Targeted Credit Programmes in Promoting Employment and Productivity of the Poor in Bangladesh, The Bangladesh Development Studies, vol.XXII:3\&2.

Roushdy \& Namoro (2007). Intrahousehold Resource Allocation in Egypt: Effect of Distribution of Power within the Household on Child Work and Schooling. University of Pittsburgh, Department of Economics, Working Papers No. 331.

Schuler, Sidney Ruth, Syed M. Hashemi \& Ann P. Riley (1997). The Influence of Changing Roles and Status in Bangladesh's Fertility Transition: Evidence from a Study of Credit Programs and Contraceptive use, World Development, vol.25:4.

Sen, Amartya (1999). Development as Freedom, Oxford: Oxford University Press. 
Stromquist, Nelly P. (1995). The Theoretical and Practical Bases for Empowerment, Women, Education and Empowerment: Pathways towards Autonomy. Carolyn Medel-Anonuevo, ed. Report of the International Seminar held at UIE, January 27-February 2, 1993, Hamburg, Germany. Paris: UNESCO.

Zohir, S. (1990). Rural Credit Market in Noakhali District, Research Report No.106, Dhaka, Bangladesh Institute of Development Studies. 
Table: 1

Dimensions of empowerment proposed by selected authors

\begin{tabular}{|l|l|}
\hline CIDA 1996 & Legal empowerment \\
& Political empowerment \\
& Economic empowerment \\
& Social empowerment \\
\hline Jejeebhoy 1995 & Knowledge autonomy \\
& Decision-making autonomy \\
& Physical autonomy \\
& Emotional autonomy \\
& Economic and Social autonomy and self-reliance \\
\hline Kishor 2000a & Financial autonomy \\
& Participation in the modern sector \\
& Lifetime exposure to employment \\
& Sharing of roles and decision-making \\
& Family structure amenable to empowerment \\
& Equality in marriage \\
(lack of) Devaluation of women
\end{tabular}


Table: 2

Indicators used for the measurement of women empowerment

\begin{tabular}{|c|c|c|c|c|c|c|}
\hline $\begin{array}{l}\text { Indicator of } \\
\text { Empowerment } \\
\text { (as dependent } \\
\text { variable) }\end{array}$ & \multicolumn{6}{|c|}{ Intermediary variables used in calculating dependent variables } \\
\hline $\begin{array}{l}\text { Decision } \\
\text { making }\end{array}$ & \multicolumn{6}{|c|}{$\begin{array}{l}\text { a. Ability to make purchases of Jewelry. } \\
\text { b. Ability to make purchases of cosmetics } \\
\text { c. Ability to make purchases of physical assets related to daily life } \\
\text { d. Ability to purchase house } \\
\text { e. Ability to purchase land } \\
\text { f. Ability to make investment / savings }\end{array}$} \\
\hline \multirow{5}{*}{$\begin{array}{l}\text { Mobility } \\
\text { (Nearby } \\
\text { Village/ } \\
\text { Own Village) }\end{array}$} & a) Can go to Market & Alone & $\begin{array}{l}\text { With } \\
\text { Children }\end{array}$ & $\begin{array}{l}\text { With A } \\
\text { Female }\end{array}$ & & $\begin{array}{l}\text { With } \\
\text { Adult } \\
\text { Male }\end{array}$ \\
\hline & b) Can go to Bank & Alone & $\begin{array}{l}\text { With } \\
\text { Children }\end{array}$ & $\begin{array}{l}\text { With } \\
\text { Adult } \\
\text { Female }\end{array}$ & & $\begin{array}{l}\text { With } \\
\text { Adult } \\
\text { Male }\end{array}$ \\
\hline & $\begin{array}{l}\text { c) Can go to } \\
\text { Hospital }\end{array}$ & Alone & $\begin{array}{l}\text { With } \\
\text { Children }\end{array}$ & $\begin{array}{l}\text { With A } \\
\text { Female }\end{array}$ & & $\begin{array}{l}\text { With } \\
\text { Adult } \\
\text { Male }\end{array}$ \\
\hline & d) Can go to field & Alone & $\begin{array}{l}\text { With } \\
\text { Children }\end{array}$ & $\begin{array}{l}\text { With A } \\
\text { Female }\end{array}$ & & $\begin{array}{l}\text { With } \\
\text { Adult } \\
\text { Male }\end{array}$ \\
\hline & $\begin{array}{l}\text { e) Can go to other } \\
\text { houses }\end{array}$ & Alone & $\begin{array}{l}\text { With } \\
\text { Children }\end{array}$ & $\begin{array}{l}\text { With A } \\
\text { Female }\end{array}$ & & $\begin{array}{l}\text { With } \\
\text { Adult } \\
\text { Male }\end{array}$ \\
\hline & i.Own House & Self & Spouse & Family & Joint & Other \\
\hline 7 & ii.Own Livestock & Self & Spouse & Family & Joint & Other \\
\hline Security & iii.Own Jewelry & Self & Spouse & Family & Joint & Other \\
\hline & $\begin{array}{l}\text { iv.Own Household } \\
\text { item }\end{array}$ & Self & Spouse & Family & Joint & Other \\
\hline Self confidence & $\begin{array}{l}\text { Participate in Bisi/ } \\
\text { Ability to move freely }\end{array}$ & $\begin{array}{l}\text { mmi } \\
\text { ithin }\end{array}$ & $\begin{array}{l}\text { e or } \mathrm{NG} \\
\text { outside th }\end{array}$ & $\begin{array}{l}\mathrm{CBO} \\
\text { village a }\end{array}$ & $\begin{array}{l}\text { ving } p \\
\text { one. }\end{array}$ & ograms \\
\hline
\end{tabular}


Table 3

Explanation of the variable used in the estimation

\begin{tabular}{|l|l|l|}
\hline S. No. & Variables & Explanation \\
\hline Dependent Variable \\
\hline A. & Empowerment Indicators (EI) \\
\hline 1. & MI & Mobility Index \\
\hline 2. & DMI & Economic Decision Making Index \\
\hline 3. & SCI & Self Confidence Index \\
\hline 4. & ECSCI & Economic Security Index \\
\hline 5. & CEI & Cumulative Empowerment Index \\
\hline Independent Variable \\
\hline A. & Credit Specific (CRDT) \\
\hline 1. & LNPREC & Loan for productive/development purpose \\
\hline 2. & LNPRCON & Loan for consumption purpose \\
\hline B. & Household Specific (HHSP) \\
\hline 1. & EDHOH & Number of years of education of head of the household \\
\hline 2. & AGEHH & Age of the household head in years \\
\hline 3. & DEPRAT & $\begin{array}{l}\text { Member aged under } 14 \text { plus those over } 65 \text {, divided by } \\
\text { household size }\end{array}$ \\
\hline 4. & PADWHH & Proportion of females aged 15-65 \\
\hline 5. & TOTY & Household income \\
\hline 6. & DPUN & Dummy variable for Punjab province \\
\hline 7. & DBAL & Dummy variable for Balochistan province \\
\hline 8. & DSIND & Dummy variable for Sindh province \\
\hline 9. & DNWFP & Dummy variable for NWFP province \\
\hline 10. & DAJK & Dummy variable for AJK province \\
\hline 11. & DSEMP & $\begin{array}{l}\text { If Household head is self employed equal to one otherwise } \\
\text { zero }\end{array}$ \\
\hline 12. & DEMPLE & If Household head is employee equal to one otherwise zero \\
\hline 13. & DUNEMP & $\begin{array}{l}\text { If Household head is currently unemployed equal to one } \\
\text { otherwise zero }\end{array}$ \\
\hline C. & Female Specific (FSP) \\
\hline 1. & AGE & Age of women \\
\hline 2. & EDUC & Number of years of education of women \\
\hline 3. & EMP & Dummy variable, 1 if women is employed 0 if not \\
\hline 4. & FMAR & $\begin{array}{l}\text { Dummy variable, } 1 \text { if women is married, } 0 \text { if not } \\
\text { Dummy } \\
\text { separated/divorced/widowed, } 0 \text { if not }\end{array}$ \\
\hline 5. & FSWD & Dummy variable, 1 if women is single, 0 if not \\
\hline 6. & FSING & \multicolumn{3}{|l|}{ is } \\
\hline
\end{tabular}


Table 4

Indices of empowerment and borrowing

\begin{tabular}{|c|c|c|c|c|c|c|c|c|c|c|}
\hline & \multicolumn{2}{|c|}{$\begin{array}{l}\text { Cumulative } \\
\text { Index }\end{array}$} & \multicolumn{2}{|c|}{$\begin{array}{l}\text { Decision-making } \\
\text { Index }\end{array}$} & \multicolumn{2}{|c|}{$\begin{array}{l}\text { Mobility } \\
\text { Index }\end{array}$} & \multicolumn{2}{|c|}{$\begin{array}{l}\text { Economic security } \\
\text { Index }\end{array}$} & \multicolumn{2}{|c|}{$\begin{array}{l}\text { Self-confidence } \\
\text { Index }\end{array}$} \\
\hline & $\begin{array}{c}\text { Non } \\
\text { Borrowers }\end{array}$ & Borrowers & $\begin{array}{c}\text { Non } \\
\text { Borrowers }\end{array}$ & Borrowers & $\begin{array}{c}\text { Non } \\
\text { Borrowers }\end{array}$ & Borrowers & $\mid \begin{array}{c}\text { Non } \\
\text { Borrowers }\end{array}$ & Borrowers & $\begin{array}{c}\text { Non } \\
\text { Borrowers }\end{array}$ & Borrowers \\
\hline $\begin{array}{c}\text { Not } \\
\text { Empowered }\end{array}$ & $\begin{array}{c}1977 \\
25.8 \%\end{array}$ & $\begin{array}{c}161 \\
16.0 \%\end{array}$ & $\begin{array}{c}3448 \\
45.0 \%\end{array}$ & $\begin{array}{c}473 \\
47.1 \%\end{array}$ & $\begin{array}{c}1857 \\
24.2 \%\end{array}$ & $\begin{array}{c}171 \\
17.0 \%\end{array}$ & $\begin{array}{c}3602 \\
47.0 \%\end{array}$ & $\begin{array}{c}291 \\
29.0 \%\end{array}$ & $\begin{array}{c}6839 \\
89.3 \%\end{array}$ & $\begin{array}{c}917 \\
91.2 \%\end{array}$ \\
\hline Empowered & $\begin{array}{c}5681 \\
74.2 \%\end{array}$ & $\begin{array}{c}844 \\
84.0 \%\end{array}$ & $\begin{array}{c}4210 \\
55.0 \%\end{array}$ & $\begin{array}{c}532 \\
52.9 \%\end{array}$ & $\begin{array}{c}5801 \\
75.8 \%\end{array}$ & $\begin{array}{c}834 \\
83.0 \%\end{array}$ & $\begin{array}{c}4056 \\
53.0 \%\end{array}$ & $\begin{array}{c}714 \\
71.0 \%\end{array}$ & $\begin{array}{c}5342 \\
10.7 \%\end{array}$ & $\begin{array}{c}818 \\
8.1 \%\end{array}$ \\
\hline & $\begin{array}{l}7658 \\
100 \%\end{array}$ & $\begin{array}{c}1005 \\
100 \%\end{array}$ & $\begin{array}{l}7658 \\
100 \%\end{array}$ & $\begin{array}{l}1005 \\
100 \%\end{array}$ & $\begin{array}{l}7658 \\
100 \%\end{array}$ & $\begin{array}{l}1005 \\
100 \%\end{array}$ & $\begin{array}{l}7658 \\
100 \%\end{array}$ & $\begin{array}{l}1005 \\
100 \%\end{array}$ & $\begin{array}{c}7658 \\
100 \%\end{array}$ & $\begin{array}{c}1005 \\
100 \%\end{array}$ \\
\hline
\end{tabular}

Note: \% represents column percentage.

Source: Authors Estimation. 
Table 5

Association between selected factors affecting empowerment and empowerment indices

\begin{tabular}{|c|c|c|c|c|c|}
\hline & $\begin{array}{l}\text { Decision } \\
\text { Making } \\
\end{array}$ & Mobility & $\begin{array}{l}\text { Economic } \\
\text { Security }\end{array}$ & $\begin{array}{c}\begin{array}{c}\text { Self- } \\
\text { confidence }\end{array} \\
\end{array}$ & $\begin{array}{c}\text { Cumulative } \\
\text { Empowerment }\end{array}$ \\
\hline \multicolumn{6}{|l|}{ Female Credit } \\
\hline Non Borrowers & 0.66 & 31.81 & 2.81 & 0.14 & 35.42 \\
\hline LT 999 & 0.64 & 32.34 & 4.34 & 0.11 & 37.43 \\
\hline $1001-5000$ & 0.72 & 32.09 & 4.18 & 0.10 & 37.10 \\
\hline $5001-10000$ & 0.70 & 37.94 & 4.35 & 0.22 & 43.21 \\
\hline $10001-25000$ & 0.73 & 41.15 & 3.94 & 0.36 & 46.18 \\
\hline 25001-hi & 0.83 & 36.17 & 5.00 & 0.00 & 42.00 \\
\hline \multicolumn{6}{|l|}{ Male Credit } \\
\hline Non Borrowers & 0.71 & 32.78 & 3.06 & 0.16 & 36.71 \\
\hline LT 999 & 0.55 & 32.23 & 2.76 & 0.12 & 35.66 \\
\hline $1001-5000$ & 0.59 & 30.53 & 3.04 & 0.09 & 34.26 \\
\hline $5001-10000$ & 0.61 & 31.69 & 2.85 & 0.16 & 35.31 \\
\hline $10001-25000$ & 0.64 & 32.05 & 2.86 & 0.17 & 35.71 \\
\hline $25001-50000$ & 0.64 & 29.49 & 2.94 & 0.10 & 33.17 \\
\hline $50001-100000$ & 0.77 & 27.86 & 2.99 & 0.05 & 31.66 \\
\hline $100001-150000$ & 0.88 & 37.38 & 2.29 & 0.31 & 40.86 \\
\hline 150001-hi & 0.85 & 28.41 & 3.85 & 0.07 & 33.17 \\
\hline \multicolumn{6}{|l|}{ Female Age } \\
\hline $15-20$ & 0.58 & 29.07 & 1.62 & 0.06 & 31.34 \\
\hline $21-30$ & 0.66 & 30.67 & 3.38 & 0.10 & 34.80 \\
\hline $31-40$ & 0.73 & 33.40 & 3.81 & 0.19 & 38.13 \\
\hline $41-50$ & 0.71 & 34.86 & 3.51 & 0.22 & 39.30 \\
\hline $51-60$ & 0.75 & 36.54 & 3.15 & 0.25 & 40.69 \\
\hline $61-70$ & 0.58 & 34.64 & 2.58 & 0.19 & 37.99 \\
\hline $71-80$ & 0.64 & 32.12 & 2.27 & 0.14 & 35.17 \\
\hline 81-hi & 0.53 & 25.96 & 1.72 & 0.13 & 28.34 \\
\hline
\end{tabular}




\begin{tabular}{|c|c|c|c|c|c|}
\hline & $\begin{array}{l}\text { Decision } \\
\text { Making }\end{array}$ & Mobility & $\begin{array}{c}\text { Economic } \\
\text { Security }\end{array}$ & $\begin{array}{c}\text { Self- } \\
\text { confidence }\end{array}$ & $\begin{array}{c}\text { Cumulative } \\
\text { Empowerment }\end{array}$ \\
\hline \multicolumn{6}{|c|}{ Female Education } \\
\hline Illiterate & 0.65 & 31.89 & 3.08 & 0.14 & 35.76 \\
\hline Primary & 0.69 & 31.50 & 2.56 & 0.10 & 34.85 \\
\hline Secondary & 0.75 & 31.99 & 2.00 & 0.12 & 34.86 \\
\hline Middle & 0.79 & 32.88 & 1.96 & 0.13 & 35.76 \\
\hline Inter & 0.78 & 32.38 & 2.00 & 0.14 & 35.29 \\
\hline Graduation & 0.94 & 39.47 & 3.16 & 0.28 & 43.84 \\
\hline Higher & 1.29 & 38.14 & 4.21 & 0.36 & 44.00 \\
\hline \multicolumn{6}{|l|}{ Marital Status } \\
\hline Single & 0.61 & 29.82 & 1.09 & 0.07 & 31.58 \\
\hline Married & 0.68 & 32.44 & 3.60 & 0.16 & 36.88 \\
\hline Divorced & 0.57 & 38.61 & 1.70 & 0.25 & 41.14 \\
\hline Widowed & 0.59 & 32.60 & 2.14 & 0.16 & 35.49 \\
\hline Separated & 0.59 & 32.91 & 1.68 & 0.09 & 35.27 \\
\hline \multicolumn{6}{|c|}{ Household Head age } \\
\hline $15-20$ & 0.79 & 30.29 & 3.26 & 0.10 & 34.45 \\
\hline $21-30$ & 0.69 & 31.21 & 3.24 & 0.15 & 35.30 \\
\hline $31-40$ & 0.64 & 31.76 & 3.22 & 0.14 & 35.76 \\
\hline $41-50$ & 0.64 & 32.06 & 2.91 & 0.14 & 35.75 \\
\hline $51-60$ & 0.66 & 32.52 & 2.73 & 0.14 & 36.05 \\
\hline $61-70$ & 0.69 & 32.82 & 2.66 & 0.13 & 36.29 \\
\hline $71-80$ & 0.65 & 32.21 & 2.92 & 0.17 & 35.95 \\
\hline 81-hi & 0.51 & 25.99 & 3.12 & 0.11 & 29.72 \\
\hline \multicolumn{6}{|c|}{ Household Head Education } \\
\hline Illiterate & 0.62 & 31.75 & 3.00 & 0.12 & 35.49 \\
\hline Primary & 0.67 & 32.43 & 2.76 & 0.15 & 36.01 \\
\hline Secondary & 0.67 & 33.50 & 2.72 & 0.16 & 37.05 \\
\hline Middle & 0.76 & 31.51 & 3.01 & 0.20 & 35.49 \\
\hline Inter & 0.80 & 30.09 & 3.46 & 0.16 & 34.51 \\
\hline Graduation & 0.96 & 28.93 & 4.65 & 0.17 & 34.71 \\
\hline
\end{tabular}




\begin{tabular}{|c|c|c|c|c|c|}
\hline & $\begin{array}{l}\text { Decision } \\
\text { Making }\end{array}$ & Mobility & $\begin{array}{c}\text { Economic } \\
\text { Security }\end{array}$ & \begin{tabular}{|c|c|} 
Self- \\
confidence
\end{tabular} & $\begin{array}{c}\text { Cumulative } \\
\text { Empowerment }\end{array}$ \\
\hline Higher & 1.14 & 32.60 & 3.79 & 0.21 & 37.74 \\
\hline \multicolumn{6}{|l|}{$\begin{array}{c}\text { Household Head } \\
\text { Occupation }\end{array}$} \\
\hline Unemployed & 0.61 & 32.55 & 2.70 & 0.06 & 35.93 \\
\hline Self Employed & 0.67 & 31.84 & 3.06 & 0.14 & 35.72 \\
\hline Employee & 0.63 & 32.20 & 2.76 & 0.15 & 35.74 \\
\hline \multicolumn{6}{|l|}{ Household Income } \\
\hline LT 15000 & 0.58 & 33.86 & 3.05 & 0.14 & 37.63 \\
\hline $15000-30000$ & 0.61 & 31.73 & 3.08 & 0.13 & 35.54 \\
\hline $30000-45000$ & 0.63 & 31.57 & 2.99 & 0.14 & 35.34 \\
\hline $45000-60000$ & 0.64 & 32.76 & 2.81 & 0.16 & 36.36 \\
\hline $60000-90000$ & 0.64 & 31.93 & 2.89 & 0.14 & 35.60 \\
\hline 90000 - HI & 0.81 & 31.46 & 3.06 & 0.14 & 35.46 \\
\hline \multicolumn{6}{|l|}{ Provinces } \\
\hline NWFP & 0.64 & 27.14 & 3.54 & 0.11 & 31.43 \\
\hline Punjab & 0.62 & 37.07 & 2.60 & 0.19 & 40.48 \\
\hline Sindh & 0.77 & 26.13 & 3.59 & 0.03 & 30.52 \\
\hline Balochistan & 0.48 & 16.27 & 3.41 & 0.06 & 20.23 \\
\hline AJK & 0.93 & 43.10 & 2.19 & 0.34 & 46.56 \\
\hline \multicolumn{6}{|l|}{ Farm Size } \\
\hline Landless & 0.60 & 32.15 & 2.82 & 0.14 & 35.72 \\
\hline Subsistence & 0.66 & 33.97 & 2.99 & 0.16 & 37.79 \\
\hline Small & 0.71 & 31.58 & 3.02 & 0.13 & 35.44 \\
\hline Medium & 0.64 & 29.10 & 3.02 & 0.12 & 32.88 \\
\hline Large & 0.79 & 26.06 & 3.51 & 0.12 & 30.48 \\
\hline
\end{tabular}

Source: Authors Estimation. 
Table -6

Dependent variable: indices of empowerment (if empower equal 1 otherwise 0)

\begin{tabular}{|c|c|c|c|c|c|}
\hline & $\begin{array}{l}\text { Decision } \\
\text { Making }\end{array}$ & Mobility & $\begin{array}{l}\text { Economic } \\
\text { Security }\end{array}$ & $\begin{array}{c}\text { Self- } \\
\text { Confidence }\end{array}$ & $\begin{array}{c}\text { Cumulative } \\
\text { Empowerment }\end{array}$ \\
\hline $\mathrm{C}$ & $\begin{array}{c}0.15 \\
(0.37)\end{array}$ & $\begin{array}{c}2.9 \\
(4.92)^{*}\end{array}$ & $\begin{array}{c}-0.698 \\
(-1.72)^{* * *}\end{array}$ & $\begin{array}{c}-4.09 \\
(-5.34) *\end{array}$ & $\begin{array}{c}2.37 \\
(4.24)^{*}\end{array}$ \\
\hline \multicolumn{6}{|l|}{ Credit } \\
\hline Productive Loan & $\begin{array}{l}0.02 \\
(0.4)\end{array}$ & $\begin{array}{c}0.23 \\
(2.42)^{* *}\end{array}$ & $\begin{array}{c}0.17 \\
(2.62)^{* *}\end{array}$ & $\begin{array}{c}0.11 \\
(1.46) \\
\end{array}$ & $\begin{array}{c}0.257 \\
(2.54)^{* *}\end{array}$ \\
\hline Consumption Loan & $\begin{array}{c}-0.06 \\
(-2.33)^{* *}\end{array}$ & $\begin{array}{c}0.58 \\
(1.62)^{* * *}\end{array}$ & $\begin{array}{c}0.13 \\
(4.6)^{*}\end{array}$ & $\begin{array}{c}-0.14 \\
(-2.97)^{* *}\end{array}$ & $\begin{array}{c}0.104 \\
(2.83) * *\end{array}$ \\
\hline Male Loan & $\begin{array}{l}-0.045 \\
(-3.7)^{*}\end{array}$ & $\begin{array}{l}0.023 \\
(1.5)\end{array}$ & $\begin{array}{c}-0.055 \\
(-4.24)^{*}\end{array}$ & $\begin{array}{c}-0.0028 \\
(-0.14)\end{array}$ & $\begin{array}{c}0.027 \\
(1.78)^{* * *}\end{array}$ \\
\hline \multicolumn{6}{|c|}{ Female Characteristics } \\
\hline Age & $\begin{array}{c}0.02 \\
(2.89) * * \\
\end{array}$ & $\begin{array}{c}0.05 \\
(5.5)^{*} \\
\end{array}$ & $\begin{array}{c}0.023 \\
(2.82)^{* *}\end{array}$ & $\begin{array}{c}0.11 \\
(7.82)^{*}\end{array}$ & $\begin{array}{c}0.055 \\
(5.97)^{*}\end{array}$ \\
\hline Age Square & $\begin{array}{l}-0.0002 \\
(-2.31)^{* *}\end{array}$ & $\begin{array}{l}-0.001 \\
(-5.2)^{*}\end{array}$ & $\begin{array}{l}-0.0004 \\
(-3.9) *\end{array}$ & $\begin{array}{c}-0.001 \\
(-6.52)^{*}\end{array}$ & $\begin{array}{c}-0.001 \\
(-5.78)^{*}\end{array}$ \\
\hline Education & $\begin{array}{c}0.041 \\
(3.89)^{*}\end{array}$ & $\begin{array}{c}-0.022 \\
(-1.7) * * *\end{array}$ & $\begin{array}{l}0.035 \\
(3.2)^{*}\end{array}$ & $\begin{array}{l}-0.003 \\
(-0.18) \\
\end{array}$ & $\begin{array}{l}-0.018 \\
(-1.46) \\
\end{array}$ \\
\hline Employment & $\begin{array}{c}0.21 \\
(4.06) \\
\end{array}$ & $\begin{array}{c}0.61 \\
(9.62)^{*}\end{array}$ & $\begin{array}{c}0.26 \\
(4.85)^{*}\end{array}$ & $\begin{array}{c}0.27 \\
(3.14)^{*}\end{array}$ & $\begin{array}{c}0.677 \\
(10.85)^{* *} \\
\end{array}$ \\
\hline Maried & $\begin{array}{c}0.228 \\
(2.23) * *\end{array}$ & $\begin{array}{c}-0.23 \\
(-1.7) * * *\end{array}$ & $\begin{array}{c}0.794 \\
(7.56)^{*}\end{array}$ & $\begin{array}{l}0.185 \\
(1.14) \\
\end{array}$ & $\begin{array}{l}0.054 \\
(0.42) \\
\end{array}$ \\
\hline Single & $\begin{array}{c}0.227 \\
(1.8) * * * \\
\end{array}$ & $\begin{array}{c}-0.40 \\
(-2.5)^{* *} \\
\end{array}$ & $\begin{array}{c}-0.90 \\
(-6.8)^{*}\end{array}$ & $\begin{array}{l}0.076 \\
(0.36) \\
\end{array}$ & $\begin{array}{c}-0.388 \\
(-2.5)^{* *}\end{array}$ \\
\hline \multicolumn{6}{|c|}{ Household Characteristics } \\
\hline Per-capita Income & $\begin{array}{c}1.97 \mathrm{E}-05 \\
(6.09)^{*}\end{array}$ & $\begin{array}{l}6.80 \mathrm{E}-06 \\
(2.096) * * \\
\end{array}$ & $\begin{array}{c}1.44 \mathrm{E}-05 \\
(4.66)^{*}\end{array}$ & $\begin{array}{c}-6.96 \mathrm{E}-06 \\
(-1.54) \\
\end{array}$ & $\begin{array}{c}1.07 \mathrm{E}-05 \\
(3.16)^{*}\end{array}$ \\
\hline Head Education & $\begin{array}{c}0.031 \\
(5.25)^{*}\end{array}$ & $\begin{array}{c}-0.022 \\
(-3.04)^{*}\end{array}$ & $\begin{array}{c}0.017 \\
(2.799)^{* *}\end{array}$ & $\begin{array}{c}0.039 \\
(4.28)^{*}\end{array}$ & $\begin{array}{c}-0.012 \\
(-1.707)^{* * *}\end{array}$ \\
\hline Head Age & $\begin{array}{l}-0.012 \\
(-1.48) \\
\end{array}$ & $\begin{array}{l}0.015 \\
(1.41)\end{array}$ & $\begin{array}{l}-0.013 \\
(-1.48)\end{array}$ & $\begin{array}{c}-0.028 \\
(-2.016) * *\end{array}$ & $\begin{array}{l}0.0129 \\
(1.258)\end{array}$ \\
\hline Head Age Square & $\begin{array}{c}0.00012 \\
(1.49)\end{array}$ & $\begin{array}{c}-0.0002 \\
(-1.92)^{* *}\end{array}$ & $\begin{array}{c}0.00015 \\
(1.67)^{* * *}\end{array}$ & $\begin{array}{l}0.0002 \\
(1.44)\end{array}$ & $\begin{array}{c}-0.0002 \\
(-1.68)^{* * *}\end{array}$ \\
\hline $\begin{array}{l}\text { Head Self } \\
\text { Employed }\end{array}$ & $\begin{array}{l}0.114 \\
(0.44) \\
\end{array}$ & $\begin{array}{c}-0.945 \\
(-2.56)^{* *}\end{array}$ & $\begin{array}{c}-0.17 \\
(-0.65)\end{array}$ & $\begin{array}{c}0.93 \\
(1.53) \\
\end{array}$ & $\begin{array}{c}-1.743 \\
(-2.14)^{* *}\end{array}$ \\
\hline Head Employee & $\begin{array}{c}0.18 \\
(0.68) \\
\end{array}$ & $\begin{array}{l}-0.71 \\
(-1.9) \\
\end{array}$ & $\begin{array}{c}-0.2 \\
(-0.46) \\
\end{array}$ & $\begin{array}{c}1.02 \\
(1.68)^{* * *}\end{array}$ & $\begin{array}{c}-0.595 \\
(-1.71)^{* * *} \\
\end{array}$ \\
\hline
\end{tabular}




\begin{tabular}{|l|c|c|c|c|c|}
\hline & $\begin{array}{c}\text { Decision } \\
\text { Making }\end{array}$ & Mobility & $\begin{array}{c}\text { Economic } \\
\text { Security }\end{array}$ & $\begin{array}{c}\text { Self- } \\
\text { Confidence }\end{array}$ & $\begin{array}{c}\text { Cumulative } \\
\text { Empowerment }\end{array}$ \\
\hline Large Land Size & 0.572 & 0.31 & 0.177 & 0.32 & -0.172 \\
& $(5.18)^{*}$ & $(-2.5)^{* *}$ & $(1.5)$ & $(1.8)^{* *}$ & $(-1.4)$ \\
\hline Medium Land & 01.84 & 0.10 & 0.09 & 0.27 & 0.029 \\
& $(2.67)^{* *}$ & $(0.92)$ & $(0.97)$ & $(1.81)^{* *}$ & $(0.267)$ \\
\hline Subsistence Land & 0.268 & 0.157 & 0.056 & 0.09 & 0.098 \\
& $(3.77)^{*}$ & $(1.76)^{*}$ & $(0.74)$ & $(0.75)$ & $(1.123)$ \\
\hline Small Land & -0.0395 & 0.17 & 0.02 & -0.085 & 0.097 \\
& $(-0.64)$ & $(2.10)^{* *}$ & $(0.34)$ & $(-0.8)$ & $(1.236)$ \\
\hline Dependency Ratio & 0.09 & 0.016 & 0.096 & -0.124 & 0.025 \\
& $(2.99)^{* *}$ & $(0.40)$ & $(2.9)^{* *}$ & $(-2.39)^{* *}$ & $(0.063)$ \\
\hline Adult Women & -1.44 & 0.57 & -0.62 & 0.569 & 0.36 \\
Proportion & $(-0.90)$ & $(2.72)^{* *}$ & $(-3.63)^{*}$ & $(2.2)^{* *}$ & $(1.79)^{* * *}$ \\
\hline Punjab & -1.04 & -1.67 & 0.17 & -0.92 & -1.699 \\
& $(-8.7)^{*}$ & $(-5.9)^{*}$ & $(1.56)$ & $(-7.03)^{*}$ & $(-6.35)^{*}$ \\
\hline NWFP & -0.912 & -3.29 & 0.69 & -1.5 & -3.09 \\
& $(-6.9)^{*}$ & $(-11.4)^{*}$ & $(5.41)^{*}$ & $(-8.62)^{*}$ & $(-11.3)^{*}$ \\
\hline Sindh & -0.595 & -2.94 & 1.12 & -2.7 & -2.99 \\
& $(-4.68)^{*}$ & $(-10.25)^{*}$ & $(9.27)^{*}$ & $(-14.42)^{*}$ & $(-11.03)^{*}$ \\
\hline Balochistan & -1.543 & -4.44 & 1.16 & -1.8 & -4.43 \\
\hline Sample & $(-10.74)^{*}$ & $(-14.98)^{*}$ & $(8.199)^{*}$ & $(-8.85)^{*}$ & $(-15.7)^{*}$ \\
\hline Log Likelihood & 8663 & 8663 & 8663 & 8663 & 8633 \\
\hline LR statistics $(25$ & -5706 & -3829.99 & -5193.2 & -2604.4 & -3942.3 \\
df.) & 519.3 & 1768.5 & 1534.2 & 600.4 & 1796.9 \\
\hline Probability LR & & & & & \\
\hline statistics & 0.000 & 0.000 & 0.000 & 0.000 & 0.000 \\
\hline
\end{tabular}

Note: Numbers in parenthesis are t-statistics.

$*, * *$ and $* * *$ represents significant at $1 \%, 5 \%$ and $10 \%$ respectively.

Source: Authors estimation.

Ambreen Fatima is an Associate Professor in the Applied Economics Research Centre, University of Karachi.

Syed Faizan Iftikhar is an Assistant Professor in the Applied Economics Research Centre, University of Karachi.

Khurram Iftikhar is Lecturer in the Applied Economics Research Centre, University of Karachi. 